\title{
КРЕМНИЙХИТОЗАНСОДЕРЖАЩИЕ СТОМАТОЛОГИЧЕСКИЕ ПЛЕНКИ ДЛЯ ЛЕЧЕНИЯ И ПРОФИЛАКТИКИ ЗАБОЛЕВАНИЙ ПОЛОСТИ РТА
}

\author{
Д.С. Тишин ${ }^{1,2}$, Е.В. Шадрина', Т.С. Бабичева ${ }^{3}$, А.Б. Шиповская ${ }^{3}$, Т.Г. Хонина'
}

${ }^{1}$ Институт органического синтеза им. И.Я. Постовского Уральского отделения Российской академии наук, 620108, Россия, г. Екатеринбург, ул. С. Ковалевской, д. 22.

${ }^{2}$ Институт естественных наук и математики, Уральский федеральный университет, 620002, Россия, г. Екатеринбург, ул. Мира, д. 19.

${ }^{3}$ Институт химии, Саратовский национальный исследовательский государственный университет им. Н.Г. Чернышевского, 410012, Россия, г. Саратов, ул. Астраханская, д. 83.

DOI: 10.19163/MedChemRussia2021-2021-315

E-mail:den.tishin@inbox.ru

Лечение и профилактика заболеваний полости рта остается одной из наиболее актуальных проблем современной стоматологии. При этом следует отметить, что при терапевтическом воздействии важная роль принадлежит лекарственной форме, в виде которой применяется действующее вещество. Стоматологические пленки являются инновационной и перспективной лекарственной формой, и в настоящее время в этом направлении проводятся активные исследования.

В данной работе стоматологические пленки были получены методом биомиметической золь-гель минерализации полисахаридов (хитозана) с использованием глицериновых растворов тетраглицеролата кремния $\mathrm{Si}\left(\mathrm{C}_{3} \mathrm{H}_{7} \mathrm{O}_{3}\right)_{4}$ в качестве биосовместимого прекурсора. Дополнительно для придания пленкам мукоадгезивности в их состав вводили поливинилпирролидон или поливиниловый спирт. Для растворения хитозана использовали водные растворы органических кислот (молочной, гликолевой и др.). Ранее тем же методом нами был получен и охарактеризован ряд новых биоактивных кремнийполисахаридсодержащих гидрогелей и тонких пластин на их основе [1].

Выбраны оптимальные составы полученных пленок, комплексом современных физических методов исследована их структура. Изучение деформационно-прочностных характеристик (разрывное напряжение, относительное удлинение при разрыве, модуль упругости) показало, что пленки обладают необходимыми мукоадгезивностью, эластичностью и прочностью. На примере НПВС исследована кинетика высвобождения лекарственных добавок.

Работа выполнена в соответствии с планами НИР и государственным заданием на 2021 г. (государственная регистрация № AAAA-A19-119011790130-3).

\section{Литература}

[1] A.B. Shipovskaya, T.G. Khonina, Yu.Yu. Zhuravleva et al. // Advances in Chemistry Research. V. 63. Taylor J.C. (ed.). New York: Nova Science Publishers, 2020. Ch. 1. P. 1-76. 